\title{
IDENTIFIKASI DAN ANALISIS POTENSI WILAYAH PESISIR SEBAGAI DASAR PEMETAAN KAWASAN KONSERVASI DI PESISIR KABUPATEN BANYUWANGI, JAWA TIMUR
}

\author{
Identification and Analysis of Potential Coastal Areas As Basis for Mapping Conservation \\ Areas in the Coastal District of Banyuwangi, East Java
}

\author{
Abu Bakar Sambah ${ }^{1,2}$, Didied Affandy ${ }^{3}$, Oktiyas Muzaky Luthfi ${ }^{4}$, Anthon Efani ${ }^{5}$
}

Diterima: 28 Juli 2019, Disetujui: 9 Oktober 2019

\author{
1,4Jurusan Pemanfaatan Sumberdaya Perikanan dan Kelautan. Fakultas Perikanan dan Ilmu Kelautan, Universitas Brawijaya. \\ ${ }^{2}$ Marine Resources Exploration and Management Research Group. Universitas Brawijaya. \\ ${ }^{3}$ Jurusan Akutansi, Fakultas Ekonomi dan Bisnis. Universitas Brawijaya. \\ ${ }^{5}$ Jurusan Sosial Ekonomi Perikanan dan Kelautan. Fakultas Perikanan dan Ilmu Kelautan, Universitas Brawijaya. \\ Kontak Penulis: \\ Abu Bakar Sambah \\ Email: absambah@ub.ac.id
}

\begin{abstract}
ABSTRAK
Isu konservasi telah menjadi perhatian global sekaligus menjadi isu strategis di berbagai negara termasuk di Indonesia. Pengelolaan potensi sumberdaya pesisir dan pulau-pulau kecil harus sejalan dengan upaya perlindungan dan pelestariannya. Kebutuhan akan rencana penyusunan zonasi kawasan konservasi perairan di wilayah Kabupaten Banyuwangi Provinsi Jawa Timur dipandang perlu dan penting untuk dilakukan, khususnya dalam upaya pembangunan yang berwawasan lingkungan dan berkelanjutan untuk menjaga dan menyamin ketersediaan sumberdaya dimasa depan. Penelitian ini bertujuan untuk melakukan identifikasi, inventarisasi, dan analisis terhadap potensi sumberdaya pesisir di wilayah Kabupaten Banyuwangi guna menjadi salah satu data dasar dalam pemetaan dan zonasi Calon Kawasan Konservasi Perairan, Pesisir dan Pulau-pulau Kecil (CKKP3K), sesuai dengan Peraturan Menteri Kelautan dan Perikanan tentang Tata Cara Penetapan Kawasan Konservasi. Kawasan konservasi perairan ditetapkan berdasarkan hasil analisis terhadap kriteria ekologi, sosial budaya dan ekonomi. Sedangkan kegiatan pemetaan dilakukan untuk melakukan penggambaran spasial terhadap calon kawasan sesuai dengan kriteria-kriteria diatas. Skoring terhadap kriteria dilakukan juga untuk mengetahui nilai potensi sebagai landasan penetapan CKKP3K. Secara umum berdasarkan hasil analisis dari kriteria ekologi yang meliputi keanekaragaman hayati, kealamiahan, keterwakilan, keunikan, daerah ruaya, habitat ikan khas/langka/unik/endemic, ikan di lindungi, daerah pemijahan ikan, dan daerah pengasuhan, menunjukkan skoring yang tinggi. Artinya beberapa kawasan secara ekologi berpotemsi sebagai kawasan konservasi. Secara kearifan lokal, beberapa kawasan juga telah memiliki pedoman yang dituangkan dalam peraturan lokal terkait kawasan konservasi. Keseluruhan hasil analisis dalam penelitian ini dapat digunakan sebagai acuan awal dalam perusmusan kebijakan terkait zonasi wilayah pesisir di Kabupaten Banyuwangi serta pengelolaannya.
\end{abstract}

Kata kunci : Pemetaan potensi; konservasi; kriteria ekologi; kriteria sosial; kriteria ekonomi.

\begin{abstract}
ABSTRACK
The issue of conservation has become a global concern as well as a strategic issue in various countries including Indonesia. The management of coastal and small island resources potential must be in line with its protection and preservation efforts. The need for zoning plans for marine conservation zones in the Banyuwangi Regency of East Java Province is necessary and important to do, especially in the development efforts that are environmentally friendly and sustainable to maintain and guarantee the availability of future resources. This study aims to identify, inventory and analyze the potential of coastal resources in the Banyuwangi Regency to be one of the basic data in mapping and zoning of Prospective Marine, Coastal, and Small Island Conservation Areas (CKKP3K), based on Minister of Marine Affairs and Fisheries Regulations concerning Procedures for Establishing Conservation Areas. Marine conservation areas are determined based on the results of an analysis of ecological, socio-cultural and economic criteria. While the mapping activities are carried out for describing the prospective areas according to the above criteria spatially. Scoring of the criteria is also carried out to determine the potential value as a basis for determining CKKP3K. In general, based on the results of the analysis of ecological criteria which include biodiversity, naturalness, representativeness, uniqueness, habitat areas, unique / rare / unique / endemic fish habitats, protected fish, fish spawning areas, and nurturing areas, show high scoring. This means that some areas are ecologically potential as conservation areas. In local wisdom, some areas also have guidelines as outlined in local regulations related to conservation areas. The overall results of the analysis in this study can be used as an initial reference in the formulation of policies related to zoning in coastal areas in Banyuwangi and its management.
\end{abstract}

Keywords: Mapping potential; conservation; ecological criteria; social criteria; economic criteria. 


\section{PENDAHULUAN}

Sebagai Negara kepulauan yang memiliki keanekaragaman hayati laut (marine biodiversity) yang tinggi, Indonesia memiliki potensi sumberdaya alam yang berlimpah, khususnya di wilayah pesisir dan pulau-pulau kecil. Wilayah pesisir dan pulau-pulau kecil Indonesia memiliki ekosistem lengkap yang berperan sebagai habitat bagi ikan dan organisme lainnya mencari makan (feeding ground), bertelur (nesting ground) dan berpijah (spawning ground). Sekitar 55\% dari seluruh produksi perikanan yang ada berasal dari wilayah pesisir, khususnya dari ekosistem padang lamun, mangrove, terumbu karang, laguna dan estuaria. Lebih dari 2000 jenis ikan dan 500 jenis terumbu karang menjadikan Negara Indonesia terkenal sebagai kawasan pusat segitiga terumbu karang (The Coral Triangle Center ). Ekosistem terumbu karang selain memiliki fungsi bagi biota laut, juga memiliki fungsi sebagai penyerap karbon, pemecah gelombang laut, penghasil ikan yang sangat berguna bagi kesejahteraan masyarakat pesisir dan pulau-pulau kecil secara khusus dan bagi seluruh rakyat Indonesia secara umumkan.

Amanat Konservasi Sumberdaya Ikan digariskan dalam Peraturan Pemerintah 60 tahun 2007 yang diikuti peraturan teknis lain berupa Pedoman dan Peraturan Menteri. Sejak lahirnya payungpayung hukum tersebut, upaya konservasi sumberdaya ikan di Indonesia semakin intensif dilakukan. Inisiatif pemerintah pusat dan daerah dalam kegiatan konservasi sumberdaya ikan hingga saat ini telah melahirkan tidak kurang dari 16 juta hektar luasan kawasan konservasi perairan pada akhir tahun 2012. Pemerintah Indonesia telah berkomitmen menggenapkan luasan kawasan konservasi perairan tersebut menjadi 20 juta hektar pada Tahun 2020. Komitmen tersebut tentunya selaras dengan komitmen bagaimana meningkatkan status pengelolaan efektif terhadap kawasan-kawasan tersebut

Salah satu program pengelolaan wilayah pesisir dan pulau-pulau kecil secara berkelanjutan dilakukan melalui konservasi yang bertujuan melindungi, melestarikan dan mengelola secara berkelanjutan sumberdaya ikan, meliputi ekosistem, jenis dan genetik ikan secara lestari dan berkelanjutan. Salah satu upaya konservasi ekosistem adalah dengan mengembangkan dan menetapkan kawasan konservasi perairan, pesisir dan pulau-pulau kecil yang dikelola dengan sistem zonasi, diantaranya zona perikanan berkelanjutan yang dapat dimanfaatkan masyarakat untuk budidaya dan penangkapan ikan ramah lingkungan serta zona pemanfaatan untuk kegiatan wisata bahari. Program ini tentunya sejalan dengan penerapan prinsip Blue Economy untuk mendukung industrialisasi kelautan dan perikanan.

Zonasi Kawasan Konservasi Perairan adalah suatu bentuk rekayasa teknis pemanfaatan ruang di kawasan konservasi perairan melalui penetapan batas-batas fungsional sesuai dengan potensi sumber daya dan daya dukung serta proses-proses ekologis yang berlangsung sebagai satu kesatuan ekosistem. Proses terbentuknya kawasan selalu dimulai dari survei lapang, sebagai klarifikasi atau identifikasi kelayakan suatu wilayah dicalonkan sebagai kawasan konservasi (perairan). Survei lapang ini akan melibatkan ahli biologi, ekologi dan sosial, untuk melakukan penilaian sumberdaya dan ekologi (resource \& ecological assessment). Pengelolaan kawasan di Indonesia dilakukan dengan sistem zonasi.

Zonasi kawasan konservasi perairan dilakukan sebagai upaya penataan kawasan berdasarkan fungsi dengan mempertimbangkan potensi sumber daya, daya dukung, dan proses-proses ekologis yang terjadi pada kawasan tersebut. Setiap zona yang telah ditetapkan memiliki kriteria sesuai dengan karakter fisik, bioekologis, kondisi sosial, ekonomi, dan budaya kawasan. Zonasi juga bermanfaat dalam mempermudah pengawasan kawasan konservasi.

\section{BAHAN DAN METODA}

Penelitian dilakukan di wilayah pesisir Kabupaten Banyuwangi. Wilayah penelitian ini terletak di ujung timur Pulau Jawa. Wilayah daratannya terdiri atas dataran tinggi berupa pegunungan yang merupakan daerah perkebunan dan dataran rendah dengan berbagai potensi pertanian, serta daerah sekitar garis pantai yang membujur dari arah utara ke selatan yang merupakan daerah penghasil berbagai biota laut. Secara geografis Kabupaten Banyuwangi terletak pada titik koordinat diantara $7^{\circ} 43^{\prime}-8^{\circ} 46^{\prime}$ Lintang Selatan dan $113^{\circ} 53^{\prime}$ - $114^{\circ} 38^{\prime}$ Bujur Timur. Kawasan pesisir di Banyuwangi terdiri dari 11 kecamatan pesisir, dan 36 desa pesisir. Desa desa pesisir ini memiliki garis pantai sepanjang 272,598 km (Tabel 6). Hampir di setiap desa pesisir terdapat Unit Pengolah ikan (UPI), sehingga jumlah UPI di Kabupaten Pesisir mencapai 309 unit. Kecamatan dengan perkembangan industri perikanan tangkap dan pengolahan ikan yang padat terdapat di Kecamatan Muncar. Lokasi ini juga merupakan tempat pelabuhan perikanan, dengan produksi perikanan tangkap terbesar kedua di Indonesia, Pelabuhan Muncar.

\section{Metoda Analisis Citra Satelit}

Analisis citra satelit digunakan untuk memetakan potensi sumberdaya pesisir di wilayah penelitian. Pendekatan analisis citra satelit yang dilakukan adalah klasifikasi tutupan lahan pesisir melalui pendekatan klasifikasi citra satelit dengan teknik klasifikasi terbimbing, pemetaan vegetasi mangrove melalui penerapan perhitungan indeks vegetasi, serta pemetaan sebaran terumbu karang di pesisir wilayah penelitian. Metoda Analisa Berdasarkan Kriteria-Kriteria dalam Menentukan Kategori dan Jenis Kawasan Konservasi 


\section{Keanekaragaman Hayati}

$$
\mathrm{H}^{\prime}=-\sum \mathrm{ni} / \mathrm{N} \mathrm{x} \log \mathrm{ni}
$$

Dimana;

$\mathrm{H}^{\prime}=$ Indeks Keanekaragaman

$\mathrm{N}$ = Jumlah total individu

$\mathrm{ni}=$ Jumlah individu dalam genus ke-i

$\mathrm{H}^{\prime}<1=$ nilai indeks keanekaragaman Rendah

$\mathrm{H}^{\prime}>1-3=$ nilai indeks keanekaragaman Sedang

$\mathrm{H}^{\prime}>3$ = nilai indeks keanekaragaman Tinggi

\section{Kealamiahan}

Perhitungan kealamiahan ekosistem/habitat dilakukan dengan menggunakan rumus:

$$
\text { Or }=(1-(\mathrm{Am} / \mathrm{An})) \times 100 \%
$$

Dimana:

Or $=$ kealamiahan $(\%)$

$\mathrm{Am}=$ luas ekosistem yang telah mengalami campur tangan manusia

An = luas ekosistem yang dinilai

\section{Keterwakilan}

Parameter ini dinilai dengan mempertimbangkan ekosistem/habitat yang bersangkutan terhadap kawasan yang dilindungi (konservasi) di suatu wilayah biogeografi atau pulau dengan perhitungan sebagai berikut :

$$
\operatorname{Pr}=(E E c / E E s) \times 100 \%
$$

Dimana:

$\operatorname{Pr}=$ Keterwakilan $(\%)$

$\mathrm{EEc}=$ Jumlah tipe ekosistem di kawasan yang dinilai

EEs = Jumlah ideal tipe ekosistem yang ada di suatu wilayah (biogeografi atau pulau).

\section{Keunikan}

Nilai yang diberikan untuk masing-masing tingkat adalah:

1. Unik $=3$ hanya terdapat di satu daerah di Indonesia

2. Cukup unik $=2$ terdapat di beberapa daerah dalam satu wilayah biogeografi yang sama.

3. Tidak unik = 1 banyak terdapat di wilayah Indonesia

\section{Daerah Ruaya}

Parameter dapat dilihat dari kondisi perairan suatu daerah, apakah daerah itu merupakan daerah migrasi bagi suatu jenis ikan, atau mamalia laut tertentu, seperti paus dan lumba-lumba. Daerah perairan yang merupakan jalur migrasi memiliki penilaian yang tinggi dalam parameter ini.

\section{Habitat Ikan khas/ langka/ Unik/ endemik}

Untuk penilaian ikan Khas/Langka/Unik/Endemik adalah:

1. Ada beberapa (>2) Jenis Ikan Khas/Langka/ Unik/Endemik: 3
2. hanya satu atau dua Jenis ikan Khas/ Langka/ Unik/ Endemik: 2

3. Tidak ada ikan langka Khas/ Langka/ Unik/ Endemik: 1

\section{Ikan di Lindungi}

Parameter ini ditentukan berdasarkan keberadaan jenis ikan yang dilindungi oleh undang-undang atau peraturan pemerintah atau peraturan menteri yang berlaku. Parameter keberadaan ikan dilindungi tersebut juga ditentukan berdasarkan kelimpahan masingmasing jenis ikan dilindungi tersebut:

\section{Ikan yang perlu dilindungi}

Parameter ini ditentukan berdasarkan keberadaan jenis ikan yang perlu dilindungi. Jenis ikan yang perlu dilindungi ini mengacu pada rencana strategis konservasi jenis ikan di Kementerian Kelautan dan Perikanan. Selain itu, parameter ini ditentukan berdasarkan kelimpahan dari masing-masing jenis ikan yang perlu di lindungi tersebut:

\section{Potensi Rekreasi dan Pariwisata}

\section{Kemudahan Mencapai Lokasi}

Perhitungan aksesibilitas dilakukan dengan rumus (Pedoman Penetapan Kriteria Kawasan Konservasi Laut, Departemen Kehutanan, 1995):

$$
\mathrm{Kp}=\text { EOs/EOc } \times 100 \%
$$

Dimana:

$\mathrm{Kp}=$ Aksesibilitas $(\%)$

$\mathrm{EOc}=$ Frekuensi kendaraan yang menuju obyek menarik

EOs $=$ Frekuensi kendaraan yang optimum menuju obyek menarik

\section{Nilai Penting Perikanan}

Nilai penting perikanan dapat diperoleh dengan menganalisis ekonomi wilayah yang akan dinilai. Analisis ekonomi wilayah dilakukan dengan menghitung LQ (Location Quotient). Analisis dengan model LQ ini digunakan untuk melihat sektor basis atau non-basis dari suatu wilayah perencanaan dan dapat digunakan untuk mengidentifikasi sektor unggulan atau keunggulan komparatif suatu wilayah. Pendekatan dengan menggunakan Metoda LQ ini adalah dengan menganalisis nilai PDRb sub sektor i di wilayah suatu kabupaten. hal ini dapat dirumuskan sebagai berikut, dimana :

$$
\mathrm{LQ}_{\mathrm{ij}}=\mathrm{X}_{\mathrm{ij}} / \mathrm{X}_{\mathrm{i} . .}
$$

$\mathrm{LQ}_{\mathrm{ij}}=$ indeks koefisien lokasi

\section{Analisa Potensi}

Analisa potensi dilakukan untuk menentukan kategori dan jenis KKP/KKP3K yang sesuai dengan tujuan pengelolaan kawasan konservasi tersebut. Kriteria tambahan yang merupakan kriteria penting 
dan berfungsi dalam memperkuat landasan penentuan jenis calon KKP/KKP3K adalah sebagai berikut :

\section{Produktivitas}

Tingkat produktifitas bisa dilihat dari chlorofil, plankton ataupun biomassa ikan. Nilai klorofil suatu kawasan bisa dihitung dengan menggunakan citra kawasan tersebut. Penghitungan plankton bisa dilakukan di laboratorium dengan membawa sampel air yang telah diberi perlakukan. Penghitungan biomassa ikan bisa dilakukan dengan pengukuran panjang ikan dengan teknik visual sensus.

\section{Keterkaitan Ekologis}

Ekosistem-ekosistem di daerah pengamatan memiliki hubungan fungsional antar habitat ekosistem dimana perubahan terhadap salah satu ekosistem akan mempengaruhi ekosistem yang lain pada daerah yang sama, misal perubahan kondisi pada ekosistem mangrove akan mempengaruhi ekosistem lain seperti ekosistem lamun atau terumbu karang.

\section{Dukungan Masyarakat}

Dalam penilaian aspirasi masyarakat, diperlukan daftar pertanyaan (questionaire) terhadap masyarakat sekitar dan atau yang mempunyai perhatian terhadap kawasan yang dinilai.

\section{Potensi Konflik Kepentingan (Stakeholder Analysis)}

Potensi konflik kepentingan dalam pengelolaan dan pemanfaatan sumberdaya alam penting untuk dinilai, karena potensi konflik dapat menjadikan suatu kawasan menjadi tidak dapat dikelola dan terawasi dengan baik, potensi konflik dapat dilihat dari hasil wawancara dengan berbagai responden yang terkait dengan kawasan, juga dilihat dari rencana tata ruang pemanfaatan kawasan, juga dilihat potensi konflik yang berasal dari faktor politik dan kepentingan ekonomi daerah.

\section{Potensi Ancaman}

Beberapa faktor utama yang mengancam kelestarian sumberdaya keanekaragaman hayati dan pesisir lautan antara lain, pemanfaatan berlebih, penggunaan alat tangkap dan tehnik yang merusak lingkungan, perubahan dan degradasi fisik habitat, pencemaran, perubahan iklim, bencana alam, dan lain-lain.

\section{Kearifan Lokal}

Penilaian terhadap kearifan lokal dapat dilihat dari masih dipeliharanya adat istiadat di masyarakat merupakan suatu kekayaan sendiri dan hal ini turut membantu dalam melestarikan sumberdaya alam yang ada.

\section{Estetika}

Keindahan alam dapat digambarkan melalui keindahan alam seperti terumbu karang di perairan, hamparan pasir putih, kebersihan lingkungan, dan ombak yang memecah serta kenyamanan berada di dalam lokasi.

\section{Penentuan Jenis Kawasan Konsevasi Perairan, Pesisir dan Pulau-Pulau Kecil}

\section{Tingkat Kesesuaian}

Tingkat Kesesuaian adalah menghitung berapa jumlah nilai yang di tentukan, sesuai dengan kriteria nilai yang ada pada kolom jenis kawasan konservasi.

Selanjutnya di hitung nilai prosentase Kesesuaian dengan rumus sebagai berikut:

$$
\mathrm{PK}=(\mathrm{TK} / \mathrm{TTK}) \times 100 \%
$$

Dimana;

PK: Prosentase Kesesuaian

TK: Tingkat Kesesuaian pada masing-masing jenis kawasan TTK: Total Tingkat Kesesuaian dari seluruh jenis kawasan berdasarkan mandat UU

\section{Pembobotan}

Pembobotan dilakukan dengan mengkalikan nilai yang telah ditentukan dengan bobot pada masing-masing.

Analisa:

$$
\mathrm{NK}=\mathrm{PK} \times \mathrm{B} \times \mathrm{N} \times 100
$$

Dimana;

NK: Nilai Kesesuaian

PK: Prosentase Kesesuaian

B: Nilai Total bobot

$\mathrm{N}$ : Angka Penilaian

Selanjutnya, Nilai Kesesuaian (NK) dari jenis calon kawasan konservasi adalah sebagai berikut:

\section{Rekomendasi Utama}

Nilai Kesesuaian (NK) yang paling tinggi adalah jenis kawasan konservasi yang paling sesuai berdasarkan penilaian yang telah dilakukan, adalah Rekomendasi Utama calon kawasan konservasi perairan.

\section{Rekomendasi Kedua}

Nilai Kesesuaian (NK) dengan nilai nomor 2 paling tinggi adalah rekomendasi kedua, untuk jenis calon kawasan konservasi perairan dan menegasikan rekomendasi utama dengan catatan bahwa pemilihan rekomendasi kedua harus dilengkapi dengan penjelasan pada keterangan tambahan sesuai dengan 1.4.3.5. kriteria tambahan.

Aplikasi program Penentuan Jenis/kategori KKP3K yang digunakan dalam penelitian ini diperoleh dari website kkji. kp3k. kkp.go.id. 


\section{HASIL DAN PEMBAHASAN}

\section{Pembatasan Calon KKP3K}

Calon Kawasan Konservasi di Kabupaten Banyuwangi ini direncanakan dengan berdasarkan dan mengacu pada (a) Rencana alokasi ruang pada dokumen RZWP3K Provinsi Jawa Timur tahun 2017-2032; dab (b) Potensi ekologi, sosial budaya, dan ekonomi wilayah kajian.Rekomendasi kawasan konservasi perairan di lokasi di petakan berdasarkan pemetaan partisipatif bersama kelompok masyarakat pengawas/pokmaswas setempat. Selain itu, sebelum pelaksanaan pemetaan partisipatif dalam menentukan kawasan konservasi, keseluruhan ruang wilayah pesisir dan perairan di Kabupaten Banyuwangi di petakan dan di analisis tingkat kelayakan dan daya dukung lahannya guna peruntukan sebagai kawasan konservasi melalui pendekatan ilmiah. Secara kajian ilmiah, kesesuaian kawasan untuk konservasi perairan sebagaimana disajikan pada peta Gambar 1.

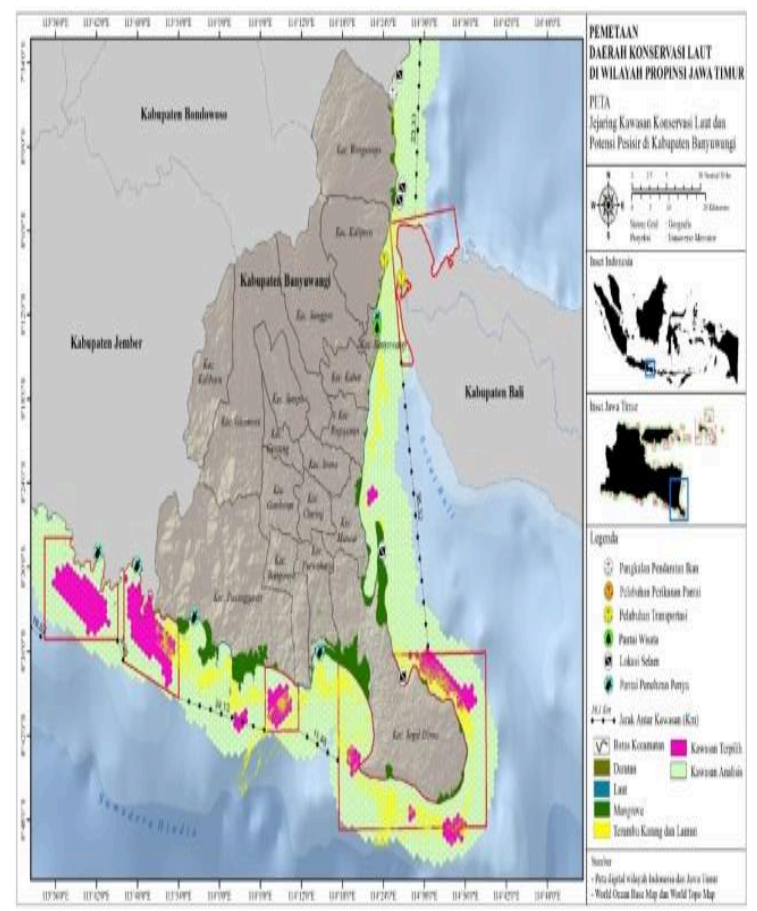

Gambar 1. Rekomendasi daerah konservasi perairan di pesisir Kabupaten Banyuwangi

\section{Hasil pemetaan Sebaran Mangrove}

Melalui analisis citra satelit dengan pendekatan indeks vegetasi, maka diperoleh sebaran vegerasi mangrove disepanjang pesisir Kabupaten Banyuwangi sebagaimana dijelaskan pada Tabel 1 dan Gambar 2.

Tabel 1. Sebaran Mangrove Wilayah Kabupaten Banyuwangi

\begin{tabular}{lllll}
\hline No & Wilayah & \multicolumn{2}{l}{ Geografis } & \multirow{2}{*}{ \%Tutupa } \\
\cline { 3 - 4 } & & Lintang S & Bujur T & n \\
\hline 1 & Sekitar & $8,4776^{0}$ & $114,3660^{0}$ & Kecil \\
& Teluk & $8,5381^{0}$ & $114,3609^{0}$ & Sedang \\
& Pangpang & $8,5098^{0}$ & $114,3892^{0}$ & Luas \\
\hline
\end{tabular}

\begin{tabular}{lllll}
\hline 2 & Sekitar & $8,6171^{0}$ & $114,2279^{0}$ & Kecil \\
& Teluk & $8,5974^{0}$ & $114,2540^{0}$ & Luas \\
& Gradjagan & $8,6139^{0}$ & $114,3566^{0}$ & Luas \\
\hline 3 & Wilayah & $8,6190^{0}$ & $114,0477^{0}$ & Luas \\
& Pesanggar & $8,5956^{0}$ & $113,9719^{0}$ & Sedang \\
& an & $8,5690^{0}$ & $113,9087^{0}$ & sedang \\
\hline 4 & Pesisir & $8,4271^{0}$ & $114,3391^{0}$ & Sedang \\
& Muncar & & & \\
\hline 5 & Wilayah & $8,0525^{0}$ & $114,4272^{0}$ & Kecil - \\
& Wongsore & $8,0125^{0}$ & $114,4230^{0}$ & Sedang \\
& jo & $7,9646^{0}$ & $114,5222^{0}$ & \\
\hline
\end{tabular}

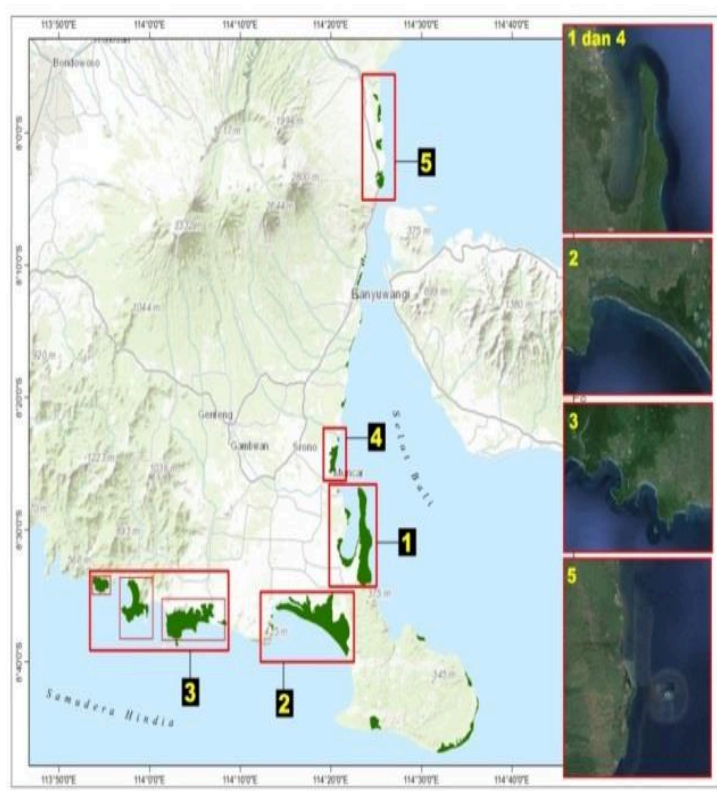

Gambar 2. Peta wilayah hutan mangrove Kabupaten Banyuwangi

Potensi hutan mangrove yang bagus dan telah dimanfaatkan sebagai kawasan ekowisata mangrove adalah wilayah-2, dimana disalah satu sisi kawasan ini terdapat ekowisata hutan mangrove yang dikenal dengan Wisata Hutan Mangrove Bedul. Wilayah wisata mangrove Bedul termasuk kawasan paling alami yang ada di Taman Nasional Alas Purwo. Wisata Hutan Mangrove Bedul berada di kawasan Segoro Anakan masuk dusun Bloksolo, Desa Sumberasri, Kecamatan Purwoharjo, Banyuwangi. Wilayah ini menjadi bagian dari kawasan Taman Nasional Alas Purwo. Wilayah ini terletak di tengah-tengah antara pantai Grajagan dan Alas Purwo serta Plengkung. Hutan mangrove di Blok Bedul tumbuh di lahan seluas 2.300 ha dan membentang sepanjang kurang lebih 16 $\mathrm{km}$ di pinggir segara anak kawasan Taman Nasional Alas Purwo dengan ketebalan mangrove rata-rata 350 $\mathrm{m}$ dari bibir Segoro Anakan Bedul. Hutan mangrove ini menjadi habitat aneka satwa seperti monyet, biawak, burung bangau, elang laut dan blibis. Bahkan pada bulan-bulan tertentu terdapat sekitar 16 jenis burung migran dari Australia, di antaranya cekakak suci (Halcyon chloris/Todirhampus sanctus), burung kirikkirik laut (Merops philippinus), trinil pantai (Actitis hypoleucos), dan trinil semak (Tringa glareola). 
Jurnal Ilmu Kelautan

SPERMONDE (2019) 5(2): 61-69

Tabel 2. Luas Wilayah Hutan Mangrove di Kabupaten Banyuwangi

\begin{tabular}{llllll}
\hline \multirow{2}{*}{ No } & Wilayah & & Luas (ha) & Panjang $(\mathrm{km})$ & Lokasi (Gambar 22) \\
\hline 1 & Sekitar Teluk Pangpang & A & $2.476,073$ & 21,9931 & \\
& & B & 445,252 & 8,2177 & \\
& C & 107,706 & 3,5478 &
\end{tabular}

\begin{tabular}{lllll}
\hline 2 & Sekitar Teluk Gradjagan & A & $3.848,469$ & 15,6949
\end{tabular}

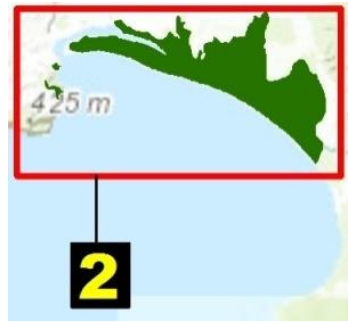

\begin{tabular}{llll}
\hline 3 Wilayah Pesanggaran & A & $2.563,828$ & 18,4549 \\
& B & 77,025 & 1,8825 \\
& C & $1.332,694$ & 17,2467 \\
& D & 498,451 & 6,2726
\end{tabular}

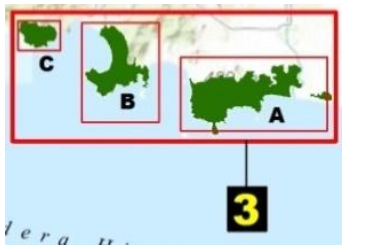

\begin{tabular}{lllll}
\hline 4 & Pesisir Muncar & A & 406,855 & 3,9173 \\
& & B & 16,276 & 0,6074
\end{tabular}

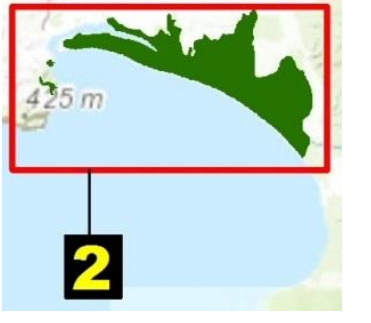

\begin{tabular}{lllll}
\hline 5 Wilayah Wongsorejo & A & 254,454 & 2,7851 \\
& B & 125,830 & 1,4188 \\
& C & 125,014 & 2,3862 \\
& D & 53,071 & 1,0375
\end{tabular}

\section{Penentuan Kategori Kawasan}

Penentuan kategori kawasan konservasi terlebih dahulu melakukan penilaian kriteria seperti yang telah dijelaskan pada Bab sebelumnya. Kegiatan selanjutnya adalah menyesuaikan dengan kriteria nilai kategori konservasi yang telah ditentukan. Kategori kawasan konservasi pesisir dan pulau-pulau kecil terdiri dari Kawasan Konservasi Pesisir dan Pulau-Pulau Kecil (KKP3K), Kawasan Konservasi Maritim (KKM),
Kawasan Konservasi Perairan (KKP), dan sempadan pantai (Peraturan Menteri KP No. PER. 17/MEN/2008 tentang Kawasan Konservasi di Wilayah Pesisir dan Pulau-Pulau Kecil) Hasil penilaian akan memberikan kekuatan dalam menentukan kategori dan jenis calon kawasan konservasi untuk dikembangkan di wilayah pesisir dan perairan Kabupaten Banyuwangi. Berdasarkan hasil penilaian sebagaimana sub-bab sebelumnya, maka kompilasi hasil penilaian secara keseluruhan ditampilkan pada Tabel 3. 
Tabel 3. Hasil penilaian kesesuaian calon kawasan konservasi perairan, pesisir dan pulau-pulau kecil di Kabupaten Banyuwangi

\begin{tabular}{|c|c|c|c|c|}
\hline & Kriteria & Penilaian & Skor & Keterangan \\
\hline A & Ekologi & & & \\
\hline 1 & $\begin{array}{l}\text { Keanekaragam } \\
\text { an hayati }\end{array}$ & sedang & 2 & Sesuai \\
\hline 2 & Kealamiahan & tinggi & 3 & $\begin{array}{l}\text { Sangat } \\
\text { sesuai }\end{array}$ \\
\hline 4 & Keterwakilan & cukup & 2 & Sesuai \\
\hline 5 & Keunikan & cukup & 2 & sesuai \\
\hline 6 & Daerah ruaya & Sedikit & 2 & Sesuai \\
\hline 7 & $\begin{array}{l}\text { Habitat ikan } \\
\text { dilindungi }\end{array}$ & cukup & 2 & Sesuai \\
\hline 8 & $\begin{array}{l}\text { Daerah } \\
\text { pemijahan ikan }\end{array}$ & sedang & 2 & Sesuai \\
\hline 9 & $\begin{array}{l}\text { Daerah } \\
\text { pengasuhan }\end{array}$ & tinggi & 3 & $\begin{array}{l}\text { Sangat } \\
\text { Sesuai }\end{array}$ \\
\hline B & Sosial dan Buday & & & \\
\hline 1 & $\begin{array}{l}\text { Dukungan } \\
\text { masyarakat }\end{array}$ & tinggi & 3 & $\begin{array}{l}\text { Sangat } \\
\text { sesuai }\end{array}$ \\
\hline 2 & $\begin{array}{l}\text { Potensi konflik } \\
\text { kepentingan }\end{array}$ & sedang & 2 & sesuai \\
\hline 3 & $\begin{array}{l}\text { Potensi } \\
\text { ancaman }\end{array}$ & sedang & 2 & sesuai \\
\hline 4 & Kearifan lokal & $\begin{array}{l}\text { ada, tidak } \\
\text { fektif }\end{array}$ & 2 & Sesuai \\
\hline 5 & $\begin{array}{l}\text { Keunikan } \\
\text { budaya }\end{array}$ & tinggi & 3 & sesuai \\
\hline $\mathrm{C}$ & Ekonomi & & & \\
\hline 1 & $\begin{array}{l}\text { Nilai penting } \\
\text { perikanan }\end{array}$ & tinggi & 3 & $\begin{array}{l}\text { Sangat } \\
\text { sesuai }\end{array}$ \\
\hline 2 & $\begin{array}{l}\text { Potensi } \\
\text { rekreasi dan } \\
\text { pariwisata }\end{array}$ & tinggi & 3 & $\begin{array}{l}\text { Sangat } \\
\text { sesuai }\end{array}$ \\
\hline
\end{tabular}

\begin{tabular}{clccc}
3 & $\begin{array}{l}\text { Pemanfaatan } \\
\text { kawasan untuk } \\
\text { pariwisata } \\
4\end{array}$ & tinggi & 3 & $\begin{array}{l}\text { Sangat } \\
\text { Sesuai }\end{array}$ \\
& $\begin{array}{l}\text { Kemudahan } \\
\text { mencapai akses }\end{array}$ & cukup & 2 & Sesuai \\
Estetika & tinggi & 3 & $\begin{array}{l}\text { Sangat } \\
\text { Sesuai }\end{array}$ \\
\hline & TOTAL NILAI & 44 & \\
\hline
\end{tabular}

Berdasarkan hasil penilaian sebagaimana tabel diatas, maka urgensi zonasi kawasan pesisir Kabupaten Banyuwangi sangatlah tinggi. Total nilai dengan nilai 44 sebagaimana analisis pada tabel diatas menunjukkan bahwa penilaian calon kawasan konservasi Kabupaten Banyuwangi termasuk dalam kategori cukup tinggi. Untuk menuntukan kategori kawasan konservasi yang akan dikembangkan, maka dilakukan penentuan calon kawasan. Penilaian dilakukan untuk menentukan apakah calon kawasan konservasi terpilih dapat dikembangkan melalui ketegori kawasan konservasi. Sesuai dengan rencana alokasi ruang yang ada dalam RZWP3K Provinsi Jawa Timur, maka penilaian terhadap beberapa calon kawasan konservasi di Kabupaten Banyuwangi telah dilakukan sesuai perhitungan potensi yang dimiliki.

Analisis terhadap hasil identifikasi dan inventarisasi skor dari tiap-tiap kriteria selanjutnya dianalisis menggunakan pedoman Penentuan Jenis/tipe/kategori Kawasan Konservasi (KKP/KKP3K) dari Direktorat Konservasi Kawasan dan Jenis Ikan Direktorat Jendral Kelautan Pesisir dan Pulau-pulau Kecil Kementerian Kelautan dan Perikanan. Tabel 4 merupakan contoh tabel yang digunakan dalam analisis penentuan jenis/tipe/kategori kawasan konservasi.

Tabel 4. Penentuan Jenis/Tipe/Kategori Kawasan Konservasi (KKP/KKP3K)

\begin{tabular}{|c|c|c|c|c|c|c|c|c|c|c|}
\hline No & Kriteria & Penilaian & TNP & TWP & SAP & SP & $\mathrm{TP}$ & TPK & SPs & SPK \\
\hline 1 & Keanekaragaman hayati & 2 & 3 & 2 & 3 & 2 & 2 & 2 & 3 & 3 \\
\hline 2 & Kealamiahan & 2 & 3 & 1 & 3 & 2 & 1 & 1 & 3 & 3 \\
\hline 3 & Keterwakilan & 2 & 3 & 1 & 3 & 2 & 1 & 1 & 3 & 3 \\
\hline 4 & Keunikan & 2 & 3 & 2 & 3 & 3 & 2 & 2 & 2 & 2 \\
\hline 5 & Daerah ruaya & 2 & 2 & 2 & 3 & 3 & 2 & 2 & 3 & 3 \\
\hline 6 & $\begin{array}{l}\text { Habitat ikan khas/langka dan } \\
\text { endemik }\end{array}$ & 2 & 3 & 2 & 3 & 3 & 2 & 2 & 3 & 3 \\
\hline 7 & Ikan dilindungi & 2 & 3 & 2 & 3 & 3 & 2 & 2 & 3 & 3 \\
\hline 8 & Ikan yang perlu dilindungi & 2 & 2 & 1 & 2 & 3 & 2 & 2 & 2 & 3 \\
\hline 9 & $\begin{array}{l}\text { Potensi rekreasi dan } \\
\text { pariwisata }\end{array}$ & 2 & 3 & 3 & 2 & 1 & 3 & 3 & 1 & 1 \\
\hline 10 & Kemudahan mencapai lokasi & 2 & 3 & 3 & 1 & 1 & 3 & 3 & 1 & 1 \\
\hline 11 & $\begin{array}{l}\text { Pemanfaatan } 67 \text { awasan untuk } \\
\text { pariwisata }\end{array}$ & 2 & 2 & 3 & 2 & 1 & 3 & 3 & 2 & 1 \\
\hline 12 & Keunikan budaya & 2 & 3 & 3 & 2 & 2 & 3 & 3 & 2 & 2 \\
\hline 13 & Daerah pemijahan ikan & 2 & 3 & 2 & 3 & 3 & 2 & 2 & 3 & 3 \\
\hline 14 & Daerah pengasuhan & 2 & 2 & 2 & 3 & 3 & 2 & 2 & 3 & 3 \\
\hline 15 & Nilai penting perikanan & 2 & 3 & 3 & 1 & 1 & 3 & 3 & 1 & 1 \\
\hline 16 & Kepentingan strategis & tidak & yа & ya & ya & ya & ya & ya & ya & ya \\
\hline
\end{tabular}




\begin{tabular}{|c|c|c|c|c|c|c|c|c|c|c|c|c|}
\hline \multirow[t]{3}{*}{17} & \multicolumn{12}{|c|}{ Calon kawasan melingkupi } \\
\hline & a & Daratan besar/pesisir & & tidak & tidak & tidak & tidak & tidak & ya & tidak & ya & tidak \\
\hline & $\mathrm{b}$ & Pulau-pulau kecil & & tidak & tidak & tidak & tidak & tidak & tidak & ya & tidak & ya \\
\hline \multicolumn{10}{|c|}{ Mandat UU 31} & \multicolumn{3}{|c|}{ Mandat UU 27} \\
\hline \multicolumn{3}{|c|}{ Score } & & $1,822.22$ & \multicolumn{3}{|l|}{$2,133.33$} & \multicolumn{2}{|c|}{$1,466.67$} & & & \\
\hline \multicolumn{3}{|c|}{ Rekomendasi CKKP3P } & & TNP & \multicolumn{5}{|l|}{ TWP } & & & \\
\hline \multirow{2}{*}{\multicolumn{3}{|c|}{ Keterangan }} & TNP & Rekom & asi Utama & & & & & & & \\
\hline & & & TWP & $\begin{array}{l}\text { Rekom } \\
\text { Alterna }\end{array}$ & & & & & & & & \\
\hline
\end{tabular}

Wilayah yang direkomendasikan sebagai daerah konservasi laut di Kabupaten Banyuwangi, merupakan wilayah Kecamatan Kabat, Kecamatan Banyuwangi, dan Kecamatan Wongsorejo, dimana batas-batas geografis nya sebagaimana tersaji pada Tabel 5.

Tabel 5 Identifikasi Lapangan Terkait Batas Geografis Lokasi Rekomendasi Daerah Konservasi Laut di Kabupaten Banyuwangi

\begin{tabular}{|c|c|c|}
\hline No. & $\begin{array}{l}\text { Zona Konservasi / } \\
\text { Desa/Kecamatan }\end{array}$ & Batasan / Penanda Alam \\
\hline 1. & $\begin{array}{l}\text { Inti } 1 \text { (Penyu) / } \\
\text { Kecamatan Kabat }\end{array}$ & $\begin{array}{l}\text { Utara : } \\
\text { Mulut muara sungai } \\
\left(-8.272698^{\circ}, 114.368970^{\circ}\right) \\
\left(-8.272580^{\circ}, 114.368777^{\circ}\right) \\
\text { Selatan : } \\
\text { Pantai sukojati } \\
\left(-8.276476^{\circ}, 114.366755^{\circ}\right) \\
\left(-8.276562^{\circ}, 114.366875^{\circ}\right)\end{array}$ \\
\hline 2. & $\begin{array}{l}\text { Inti } 2 \text { (Mangrove, } \\
\text { Bangau, Elang laut, } \\
\text { Buaya muara) / } \\
\text { Kecamatan Kabat }\end{array}$ & $\begin{array}{l}\text { Utara: } \\
\text { Warung } \\
-8.270812^{\circ}, 114.363838^{\circ} \\
\text { Selatan : } \\
\text { Mangrove } \\
-8.272842^{\circ}, 114.362318^{\circ}\end{array}$ \\
\hline 3. & $\begin{array}{l}\text { Inti } 1 \text { (Penyu) / } \\
\text { Kecamatan Pakis }\end{array}$ & $\begin{array}{l}\text { Selatan : } \\
\text { Pagar zona inti hutan kota } \\
\left(-8.262198^{\circ}, 114.373594^{\circ}\right) \\
\left(-8.262533^{\circ}, 114.374103^{\circ}\right) \\
\text { Utara : } \\
\text { Batas desa } \\
\left(-8.257999^{\circ}, 114.376948^{\circ}\right) \\
\left(-8.257962^{\circ}, 114.376854^{\circ}\right)\end{array}$ \\
\hline 4. & $\begin{array}{l}\text { Inti } 2 \text { (Cemara Laut) } \\
\text { / Kecamatan Pakis1 }\end{array}$ & $\begin{array}{l}\text { Selatan: } \\
\text { Pagar pembatas buatan } \\
\text { pokmaswas } \\
-8.262198^{\circ}, 114.373594^{\circ} \\
\text { Utara : } \\
\text { Ladang kosong } \\
-8.258835^{\circ}, 114.375854^{\circ}\end{array}$ \\
\hline 5 & $\begin{array}{l}\text { Zona Pemanfaatan } \\
\text { Bersama / } \\
\text { Bangsring }\end{array}$ & $\begin{array}{l}\underline{\text { Batas 1 }} \\
-8.054457^{\circ}, 114.433012^{\circ} \\
\underline{\text { Batas 2 }} \\
-8.049377^{\circ}, 114.431848^{\circ} \\
\underline{\text { Batas 3 }} \\
-8.049611^{\circ}, 114.430222^{\circ} \\
\underline{-8.054747^{\circ}}, 114.431086^{\circ}\end{array}$ \\
\hline 6 & $\begin{array}{l}\text { Zona Inti / } \\
\text { Bangsring }\end{array}$ & $-8.052^{\circ}, 114.431722^{\circ}$ \\
\hline
\end{tabular}

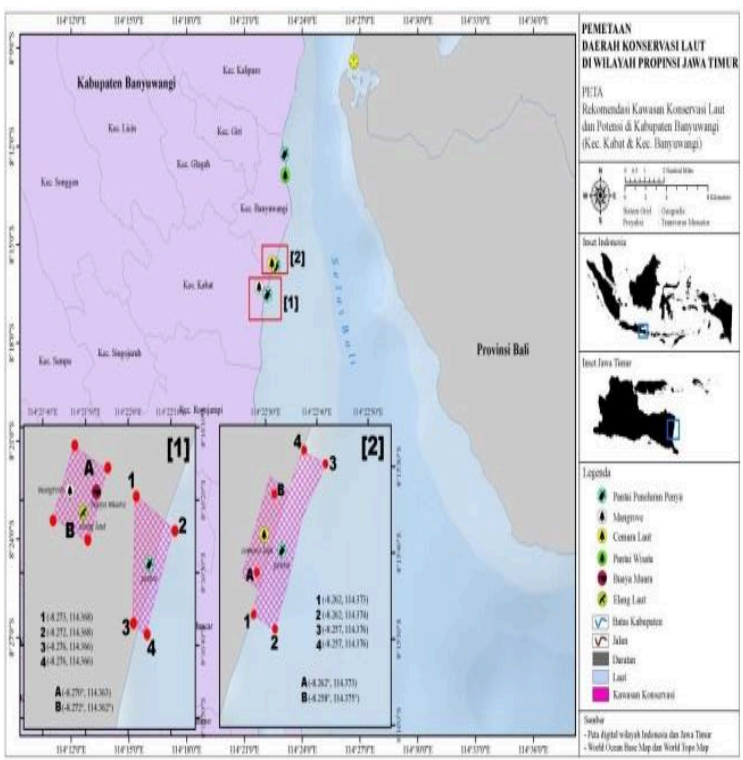

Gambar 3. Peta Rekomendasi Kawasan Konservasi Laut Serta Potensi Ekosistemnya di Wilayah Kecamatan Kabat dan Kecamatan Banyuwangi, Kabupaten Banyuwangi

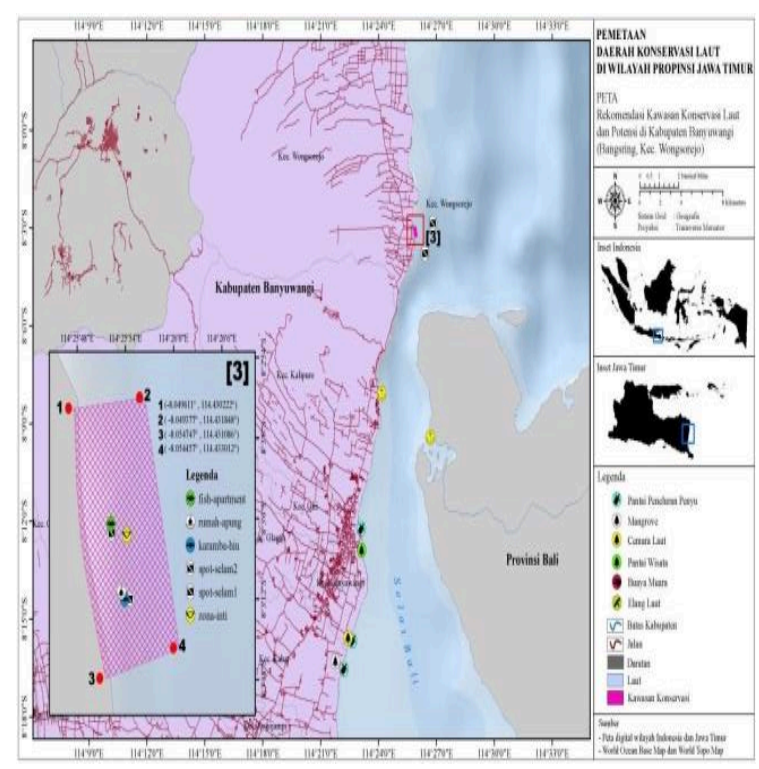

Gambar 4. Peta Rekomendasi Kawasan Konservasi Laut Serta Potensi Ekosistemnya di Wilayah Kecamatan Wongsorejo, Kabupaten Banyuwangi 


\section{KESIMPULAN}

Kegiatan zonasi kawasan pesisir ini mempunyai tujuan untuk memutakhirkan data dan informasi keberadaan kawasan konservasi dan elemen-elemen pendukungnya (zonasi, unit pengelola, dan rencana pengelolaan); guna mengumpulkan data dan informasi terkait calon Kawasan Konservasi Perairan, Pesisir dan Pulau-pulau Kecil yang baru (penambahan kawasan dan/atau luas kawasan) dengan batas kawasan yang jelas (ditandai dengan tanda batas kawasan). Rencana pengelolaan dan zonasi kawasan konservasi di Kabupaten Banyuwangi ini akan menjadi acuan dalam penyusunan rencana kerja tahunan satuan organisasi unit pengelola kawasan konservasi Kabupaten Banyuwangi. Pengelolaan kawasan konservasi merupakan sesuatu yang bersifat dinamis dan adaptif, untuk itu maka kegiatan monitoring dan evaluasi terhadap rencana pengelolaan nya harus dilakukan secara berkala. Evaluasi terhadap program dapat dilakukan dalam kurun waktu 1 tahun hingga 5 tahun, tentunya dengan mempertimbangkan pengaruh kondisi lingkungan.

\section{UCAPAN TERIMA KASIH}

Terima kasih kepada Dinas Kelautan dan Perikanan Provinsi Jawa Timur atas bantuan data melalui kajian pemetaan daerah konservasi di pesisir jawa timur. Ucapan terima kasih juga ditujukan kepada Laboratorium Eksplorasi Sumberdaya Perikanan dan Kelautan, Fakultas Perikanan dan Ilmu Kelautan, Universitas Brawijaya

\section{DAFTAR PUSTAKA}

Keputusan Bersama Badan Permusyawaratan Desa Bomo Kecamatan Rogojampi Dan Kepala Desa Bomo Kecamatan Rogojampi Nomor : 005 IBPD 1429.5a7.A412013, Nomor : 14015614291.507.0412013 Tentang Persetujuan Bersama Terhadap Penetapan Rencana Peraturan Desa Bomo Kecamatan
Rogojampi Menjadi Perturan Desa Bomo Kecamatan Rogojampi Tentang Pengelolaan Konservasi Perlindungan Bersama (KPB) Sumberdaya Laut Desa Bomo Kecamatan Rogojampi Kabupaten Banyuwangi

Pedoman Penetapan Kriteria Kawasan Konservasi Laut, Departemen Kehutanan, 1995): Pedoman Penilaian Efektifitas Kawasan Konservasi Perairan Pesisir dan Pulau-pulau Kecil

Peraturan Menteri KP No. PER. 17/MEN/2008 tentang Kawasan Konservasi di Wilayah Pesisir dan Pulau-Pulau Kecil

Peraturan Desa Sukojati, Nomor: 188/03/429.506/2014

Tentang Daerah Perlindungan Pesisir (DPS) Desa Sukojati

Peraturan Desa Pondok Nongko, Nomor: 523.3/01/429.506.09/2015 Tentang Daerah Perlindungan Pesisir Muara Sungai (DPMS) Desa Pondok Nongko

Peraturan Desa Wringin Putih Kecamatan Muncar Kabupaten Banyuwangi, No. 03 Tahun 2003

Tentang Penetapan Pengelolaan Kawasan Lindung Ekosistem Jalur Hijau Hutan Mangrove Berbasis Pada Masyarakat Setempat

Peraturan Desa Sumberagung Nomor 07 Tahun 2013

Tentang Zona Perlindungan Bersama (ZPB)

Sumberdaya Laut Desa Sumberagung Kecamatan Pesanggaran Kabupaten Banyuwangi
Peraturan Desa Kedungasri Nomor: 188/06/429.514.03/Tahun 2015 Tentang Daerah Perlindungan Pesisir (DPS) Desa Kedungasri

Suplemen Panduan Identifikasi, Inventarisasi Dan Pencadangan Kawasan Konservasi Perairan, Pesisir, Dan Pulau-Pulau Kecil. 